\title{
Milletlerarası vergi mükerrerliği ve bunu önleme çareleri
}

\author{
Turhan Feyzioğlu \\ Siyasal Bilgiler okulunda asistan
}

Bir mükellefin, ayni mevzu üzerinden ve ayni mükellefiyet devresi içinde, ayni mahiyette iki veya daha fazla vergiye tâbi tutulmasma vergi mükerrerliği (double imposition $=$ double taxation $=$ Dopfelbesteuerung) derler. Gerek maliyecileri, gerek Devletler Hukuku mensuplarını pek çok işgal eden bu hâdise en ziyade veraset, umumî gelir, menkul kiymet ve şirket vergilerinde görülür.

Hemen tebarüz ettirelim ki, vergi mükerrerliğinin karakteristik unsurları hakkında müellifler tam bir anlaşmaya varamamışlardır. Alman maliyecisi Geyler tarafından 1931 de neşredilen "Steuerliche Mehrfachbelastungen und ihre normative Abwehr) (Verginin tekerrürü ve bunu önleyecek kaideler) adlı 600 küsur sahifelik eserin hemen hemen münhasıran "mükerrer vergi" nin tarifine tahsis edilmiş olması ve bu konudaki mühim eserlerde "tarif» bahsinin geniş bir yer tutmas1, meselenin nekadar ihtilâflı olduğunu göstermeğe kâfidir (1). Biz burada, kesin bir sonuca bağlanmayan nazarî münakaşalara girişmektense. - - birçok müelliflerin yaptığı gibi - yukardaki kısa tarifle iktifa edip (2), mükerrer verginin mahiyetini bir kaç misalle aydınlatmayı daha doğru buluyoruz.

A memleketinde oturan bir mükellefin B memleketinde sinaî veya ticarî bir teşebbüse giriștiğini farzedelim. A memleketi gelir sahibinin kendi memleketi dahilinde oturmasını esas ittihaz ede-

(1) Allix, Répétitions écrites de Science financière, Paris, $1937-1938$ s. 5 - 38. (Mükerrer vergi hakkında bir doktora kurudur).

(2) F. H. Sur, Maliye dersieri, Ankara, 1945, s. 142.

Bu tarif. İsviçre federal mahkemesinin 12 şubat 1875 tarihli bir kararında yaptığı tarife de uymaktadır. (Allix, s. g. e., s. 10). 
rek, B memleketi ise gelirin kendi memleketinden neşet ettiğini göz önünde tutarak, ayni mükellefi, ayni mevzu üzerinden, ayni mahiyette iki vergiye maruz burakabilirler. - Veya muhtelif memleketlerde şubeleri olan bir şirket, bu memleketlerin her birinde şubelerinin kazançları dolayısiyle vergi ödedikten sonra, merkezinin bulunduğu memlekette de kârın yekûnu üzerinden bir vergi öder. Veraset vergilerinde de sık sık mükerrerlik husule gelir. A memleketinde oturan bir kimsenin ölümü neticesinde, B memleketinde bulunan bir takım malların C memleketindeki bir vârise isabet ettiğini farzedelim. Bu üç memleketin veraset vergisi sistemleri farklı olabilir. Vergi, A memleketinin mevzuatına göre müteveffanın ikametgâhında, B memleketinin kanunlarına göre malların bulunduğu yerde, $\mathrm{C}$ memleketinin sistemine göre de vârisin ikametgâhında ödenmek icap edebilir. Bu takdirde terekenin ne kadar ağır bir vergiye maruz kalacağını anlamak güç değildir. Bir çok hallerde, vergi nisbeti \% 100 ù bile aşmaktadır (3).

Zamanımızda vergi mükerrerliklerinin artmasını intaç eden sebepleri ve bundan doğan maddî, manevî zararları incelemiye bașlamadan önce, bütün vergi mükerrerliklerinin ayni mahiyette bulunmadı̆̆ını belirtmek faydasız olmıyacaktır. Filhakikà vergi mükerrerlikleri kasdî veya gayri kasdî diye ikiye ayrılabilir. Keza ayni devletin vergilerinde mükerrerlik olabileceği gibi, muhtelif devletlerin alacağı vergiler de mükerrerliğe yol açabilir. İsteyerek yapılan mükerrerlikiere misal olarak: şirketlerden alınan vergiler (4), veya vatandaşları memlekette kazandıkları paraları hariçte yemelerini (absentéisme'i) önlemek maksadıyla yapılan mükerrerlikler; emekle elde edilen gelirleri emek karşllığı olmıyan gelirlerden ayırmak ga-

(3) Bk. Bath. - Raynaud, La vie économique internationale, 1926; böl. IV, s. 299; (Allix'den naklen, s. g. e., s. 7); I. Fazıl Pelin, Finans ilmi ve finansal kanunlar, ikinci bas1, İstanbul, 1942 s. 234.

(4) Hẹm şirketin umumî kârı, hem de hissedarlara düşen miktarlar ayrı ayrı vergilete tâbi tutulunca, iktisaden bir mükerrerlik mevcut olduğu mchakkaktır. Fakat birçokları şirketin ayrı bir hükmî şahsiyeti bulunduğunu iddia ederek burada hukuken bir mükerrerlik bahis mevzuu olmadığını ileri sürmektedirler. Bazılarına göre de mükerrerlik vardır, fakat gayet yerindedir: Çünkü șirket fertlerin malik olmadıł̆ı geniş ve kolay kazanł̧ imkânlarına maliktir.

Bu mesele hakkunda Bk. Pelin. s. g. e., s. 231 ve 401 - 402; F. H. Sur, s. g. e., s. 143; Allix, s. s. e., s. 14 - 15, 34 - 35, 114 - 127; Allix, Traité élèmentaire..., s. 359; Jeze, Cours..., 1933, s. 115; Jens Jessen, Deutsche Finanzwirtschaft, Hamburg, 1937, s. 132; K. Teodor von Eheberg, Grundriss der Finanzwissenschaft, Leipzig, 1936, s. 87. 
yesiyle bu sonunculara yüklenen munzam mükellefiyetler gösterilebilir. Keza yerli sermayelerin yabancı memleketlere akmasin1, yabanct sermayenin memleketi istilâ etmesini önlemek gayesiyle, yahut mukabelei bilmisil olarak kasdî mükerrerlikler yapıldığı vâkidir. Fakat vergi mükerrerliği deyince, daha ziyade, kanun yapanların maksatları dışında husule gelen mükerrerlikler anlașılır.

Mükerrerliğin ayni devlet içinde mi, yoksa muhtelif devletlerin aldıkları vergiler yüzünden mi husule geldiği noktasından yapılan tasnif daha önemlidir. Ayni devlet içindeki tekerrürler, ya doğrudan doğruya merkezî devletin vergileri, ya merkezî devletle mahallî idarelerin vergileri, yahut da federal devletle federe devletlerin vergileri acasinda husule gelir. Hukukçuları ve maliyecileri bilhassa uğraştıran, birçok milletler arası teşekküllerin harekete geçmesini intaç eden hâdise, muhtelif devletlerin aldıkları vergiler dolayısiyIa husule gelen tekerrürdür. Zaten bu yazmm konusunu da Milletlerarası vergi mükerrerliği ve bunu önleme çareleri teşkil etmektedir.

Vergi mükerrerliklerinin artı̧ sebepleri: (5) Son yüzyıl içinde, milletler arası iktisadî münasebetlerin gösterdiği büyük gelişme, vergi mükerrerliklerinin gitgide ehemmiyet kazanması neticesini doğurmuştur. İktisadî münasebetlerin artmasında her şeyden önce münakale vasitalarının inkişafı müessir olmuştur. Mesafeler âdeta kısalmış, insanların ve eşyaların yer değiştirmesi son derece kolaylaşmıştır. Diğer taraftan makineye dayanan büyük istihsal mahallî veya millî pazarla iktifa eđemediği için, dış pazarlarla alışveriş artmıştır. XIX. cu asır ortalarında Avrupada hâkim olan liberal rejim de dış ticaretin gelişmesine tesir etmiştir. Diğer taraftan istihsal metodları değişmiş, ferdî teşekbüislerin yanıbaşurida, geniş ölçüde istihsal yapan büyük şirketler kurulmuştur. $\mathrm{Bu}$ şirketler muhtelif memleketlere dal budak salmış; şubeler açmış; aralarında trust, holding şeklinde bir takım kombinezonlar kurmuşlardır. Bütün bunlar siyasî sunırları kat'eden girift iktisadî alâkalar doğurmuştur. Menkul servetler çoğalmış ve sermayelerin akıcılığı artmıştır. Hele bankacılığın inkişafı ile muazzam servetlerin bir memleketten ötekine nakli son derece kolaylaşmıștır. Insanlar da daha çok seyahat etmeğe, daha sık yer değiştirmeğe başlamışlardır.

(5) Bk. F. H. Sur,s. g. e., s. 142; İ. F. Pelin, s. g. e., s. 233 - 234; Jèze, s. g. e., s. 113; Allix, Traité élém., s. $560-561$; Allix. Répétitons .écrites, s. 37 ve bilhassa s. $46-50$. 
Bundan başka, kamu masraflarının büyük bir hızla artması yüzünden her memlekette vergiler çoğalmış ve tenevvü kazanmıştır; üstelik nisbetler de yükseltilmiştir. Bu yüzden vergi mükerrerlikleri hem siklaşmış, hem de ezici bir hal almağa başlamıştır. Milliyet fikirlerinin bir çok yerlerde ecnebi aleyhtarĭlğına kadar gitmesi ve yukarda kısaca işaret ettiğimiz bazı iktisadî siyaset mülâhazaları da kasdî mükerrerliklere yol açmıştır. Diğer taraftan ,bilhassa Birinci Dünya Harbinden sonra himayecilik cereyamınn alıp yürümesi üzerine, mallarının gümrük duvarları ile karşılaşacağını gören birçok ihracatçı sanayiciler, bizzat satış mahallinde şubeler açıp istihsalde bulunmak yolunu tutmuşlardır. Nihayet, bütün bu mütenevvi sebeplerden başka, maliye tekniğinde husule gelen değgişme de vergi mükerrerliğinin geniş ölçüde artmasını mucip olmuştur. Gerçekten, bütün ileri memleketlerde,aynî vergilerin aleyhine olarak, şahsî vergiler revaç buimuştur. Yalnız muayyen malları veva gelir nevilerini göz önünde tutan aynî vergilerin yerine, mükellefin bütün gelirine başvuran ve ailevî, zatî durumunu da göz önünde tutan şahsî vergiler kaim olmuştur. Birçok memleketlerde, ayr irat vergileri. (arazi, bina, kazanç vergileri) terkedilerek, şahsî vergilerin en iyi örneği olan umumî gelir vergileri kabul edilmiştir. Toprağa, gayri menkule, dış karinelere bağh olan aynî vergiler ancak millî makamlar tarafından vergiye tâbi tutulabilirdi. Şahsî vergiler ise mükellefin - yabanc memleketlerden neşet edenler de dahil olmak üzere -bütün gelirini hesaba kattığı için, gelirin kaynağı olan memleketin vergi sistemi ile, mükellefin mukim bulunduğu memleketin sistemi umumiyetle çatışacak, her iki tarafm malî makamları da kendilerini vergi almakta hakhı görecekti. Bütün bu saydığımız âmiller, vergi mükerrerliği ihtimallerini artırmak suretile, bir takım ağır sonuçlar doğurmuştur.

Vergi mükerrertiklerinin mahzurlan: (6) Vergi mükerrerliğinin en başta gelen mahzuru, hiç şüphesiz, verginin müsaviliği kaidesini ihlâl ederek ve mükellefi ezici bir yük altında bırakarak adaletsiz-

(6) Allix, Répétitions écrites, s. 50.; Rapport du comité des savants, I ère Partie, (conséquences économiques); raporun tahilii, s. $62-68 ; \mathrm{F}$. H. Sur, Maliye dersteri, s. 144 - 145; İ, F. Pelin, s. g. e., s. 232 - 233; Jèze, s..g. e., s. 115 - 116; Seligman, Double imposition et coopération fiscale internationale, Recueil des Cours de 1'Académie de Droit international. 1927, t. 20 s. 553 556; A. N. Sack, La double imposition et l'allégement de sa charge dans les travaux de 1a S. D. N., Revue générale de droit international Public 1930, s. 99 ve müt. 
liğe sebebiyet vermesidir. Sadece yabanclların menfaatlerini ihlâl eden bir mükerrerliğin dahi fena olduğu bugün bütün müelliflerce kabul edilmektedir. Yabancıyı ezmek ahlâkî bir hareket sayılamıyacağı gibi, siyaseten de hatalıdır: çünkü mukabil tedbirlere yol açar. Türkiye İran tebaalarını mükerrer bir vergiye maruz bırakırsa, Iran da Türkiye tâbiiyetindeki kimselere ayni şekilde muamele yapacaktır. Bunlar milletler arası iyi münasebetlerin ihlâline de müncer olabilir.

Mükerrer verginin dünya iktisadiyatı bakımından da zararlı olacağ $\breve{1}_{1}$ belirtilmiştir. Ezcümle Alman müelliflerinden Dorn, bu yüzden, iktisadî faaliyetlerin, en uygun tabiat ve iktisat şartlarının toplandiğ yerlerde değil de, malî yüklerin en hafif olduğu memleketlerde tekâsüf edeceğine dikkati çekmiştir. İstihsal kuvvetleri sun'î ve irasyonel bir şekilde dağılacaktır. Milletlerarası Ticaret odası da, 1923 Viyana kongresinde, mükerrer verginin bazı mahzurlarını kuvvetle belirtmiştir: mükerrer vergi sermayelerin serbest tedavülüne engel olur; bilhassa şubeli teşebbüsler için ezici bir yük teşkil eder; milletlerarası münasebetler bakımından maddî, manevî büyük zararlar doğurur.

Milletler cemiyeti tarafundan mükerrer vergi meselesini incelemeğe memur edilen Âlimler komitesi de, 1923 te verdiği ve biraz sonra tahlil edeceğimiz raporunun birinci kısmını, vergi mükerrerliğinin iktisadî sonuçlarına tahsis etmiştir. Mütehassıslara göre, vergi kendisini iki şekilde hissettirir: Mükellefler üzerinde bir yük teşkil eder - ve servetlerin serbestçe tedavülüne engel olur. Mütehassıslar Moranya adını verdikleri farazî bir devleti ele alarak şöyle bir muhakeme yürütürler: Moranya yabancı șermayelere başvuran bir memlekettir; fakat günün birinde yabanc1 sermayelerden bir vergi almağa başlıyor. Verginin konmasından önce yapllmış plâsmanların sahipleri için vergi ağır bir yük teşkil edecektir. Fakat daha sonra yapılacak plâsmanlar bakımından, vergi bir engel olarak kendini hissettirecektir. Gerçekten sermayelerini şuraya veya buraya yatırmakta serbest bulunan kapitalistler, daima kendileri için en kấrlı olan yolu seçerler. Moranyanın ecnebi sermayeleri vergiye tâbi tutması karşısında şu iki şıktan birini tercih edeceklerdir: ya bu memlekete sermaye yatırmaktan tamamiyle vazgeçeceklerdir, - ki bu takdirde Moranyada iktisadî hayat kismen sekteye uğriyacak, faiz haddi ve istihsal masrafları artacaktır -; yahut da sermayelerini daha ağır şartlarla yatıracaklardır. Meselâ gayri safì gelirin $\% 20$ sini alan bir vergi konmuşsa, sermayedarlar $\% 5$ faiz yerine 
\% 6,25 faiz istiyeceklerdir. Hattâ, ilerde konması muhtemel olan vergileri de hesaba katarak, daha ihtiyatlı davranmaları ve 6,25 ten de yüksekk bir faiz istemeleri mümkündür. Neticede, vergi mükerrerlĭğinin asıl yükünü yabanc1 sermayeleri deģ̧il, bunlara muhtaç bulunan memleket çekecektir. Mütehassısların vardıkları sonuç şudur: yabancı sermayeleri vergiye tâbi tutarak bunları muikerrer bir mükellefiyete maruz kılmak daima borçlu memleketin zararınadir.

Hulâsa, vergi mükerrerliğinin iktisadî ve hukukî, maddì ve manevî cephelerden bir takım mühim mahzurları vardır. İşte bu yüzden, vergi mükerrerliği meselesi bütün memleketlerin hukukçu ve maliyecilerini bir hayli işgal etmiş, son derece geniş neşriyata sebebiyet vermiştir; bir çok milletlerarası teşekküller de bu ile uğraşmak mecburivetini hissetmişlerdir. Şimdi bu alandaki çalışmaları ve bultunan çareleri kısaca gözden geçirelim.

Yapllan çalısmalar ve teklif edilen çareler: (7) Milletlerarast vergi mükerrerliklerini önlemêk için almabilecek tedbirleri $t \mathrm{e} k$ $\mathrm{t}$ a $\mathrm{r}$ a $\mathrm{I}$ । ve ç ok $\mathrm{t}$ ar a fl 1 olmak üzere ikive ovırabiliriz. Tek taraflı tedbirler, bir devletin kendiliğinden, iktisadî siyaset veya adalet mülâhazalariyla aldığ̀ tedbirlerdir. Meselâ karșı!lılı bir anlaşmaya müstenit olmaksızın, Moranya devletí, bașka devJetlere ödendiği resmî vesikalarla isbat edilen gelir vergilerini kendi alacağı vergiden tenzil edebilir. Fakat her Devletin kendiliğinden iç mevzuatı koyacağı dağımı hükümlerle bu büyük davanın halledilmesine imkân olmadığı ve daha şümullü tedbirler bulmak icap ettiği çok geçmeden anlaşılmıştır. Bunun üzerine, bazı milletlerarası teşekküller bu mesele ile meşgul olmıya başlamıştır. 1919 da Brükselde toplanan Parlâmentolar arası konferans, 1921 milletlerarası Deniz Konferansı, çalışmaları arasında bu konuya da yer vermişlerdir. Fakat vergi mükerrerliği meselesini en esaslı şekilde ele alan

(7) Jéze; s. g. e., s. 116 - 117; F. H. Sur s. g. e., 146 - 147; İ. F. Pelin, s. \&. e., 234 - 239; Allix Traité élémentaire, s. 561 - 567; A. N. Sack, s. g. makale, Revue générale de droit .international public, .1930; s. 129 - 143; Seligman,s. \&. makale, Recueil des Cours, 1927, t. 20. \$. 552 - 585; Niboyet, Les doubles impositions au point de vue juridique, s. 52 - 100, Recueil des Cours, 1930, t. 31; Allix, Répétitions écrites (doktora kuru), .1937 - 1938; Benvenuto Griziotti, L'imposition fiscale des étrangers, Recueil des Cours, 1926, t. 13; Luigi Einaudi, La coopération internationale en matière fiscale, Recueil des Cours, 1928. t. 25, s. 5 ve müt; Milletler cemiyeti malî komitesinin raporu, Maliye mecmuası, sayı 5 ve 6 . 
teşekküller: Devletler Hukuku Enstitüsü, Milletler arası Ticaret odas1 ve Milletler Cemiyetidir.

1873 de kurulan Devletler Hukuku Enstitüsü, 1897 Kopenhag toplantısinda veraset vergilerinde husule gelen milletlerarası vergi mükerrerliği meselesi ile meşgul olmuştur. Bu içtimada mevcut sistemlerin tesbiti ile iktifa edilmiş, fakat 1922 Grenoble içtimainda, uzun tartışmalardan sonra, veraset vergileri hakkında şöyle bir karara varılmıştır: vergi almak hakkı müteveffanın sun ikametgâhının bulunduğu memlekete ait olmalı, yalnız terekedeki taşınmaz mallar (gayri menkuller) kâin oldukları memlekette verợiye tâbi tutulmalidır.

1920 de kurulan Milletler arasi Ticaret Odası da, kurulus gününden itibaren vergi mükerrerliği meselesi ile uğraşmağa başlamıs; bu iş için hususî bir komite teşkil etmiştir. Bu komitenin raporunda, bilhassa, vergi bakımından yabanclarmn da vatandaşlar gibi muamele görmesi gerektiğine işaret ediliyor ve yabancı memleketlerde elde edilen kazançlardan dolayı orada ödenmiş olan vergilerin umumî vergi yekûnundan indirilmesi tavsiye olunuyordu.

Milletler Cemiyetinin de bu meseleyi ele alması istendi. Bunun üzerine, 1921 de dört iktisatçı mütehassıstan müteşekkil bir Âtimler komitesi teşkil edildi. Columbia üniversitesinden Prof. Seligman, Rotterdam yüksek ticaret okulundan Prof. Bruins, Londra üniversitesinden. Prof. Stamp, ve Torino üniversitesinden Prof. Luigi Einaudi'nin iștira kettiği bu komite, raporunu 1923 te Milletler Cemiyetine verdi.

Diğer taraftan, meseleyi teknik ve idarî cephecien incelemek üzere ,yüksek maliye memurlarından ve tatbikatçılardan müteşekkil ve daha kalabalık ikinci bir komite kuruldu. 1922 de çalışmaya başliyan bu Teknisyenler komitesi de raporunu 1925 te hazırlayıp verdi. Bu raporda komitenin biraz daha genişletilmesi ve çeşitli vergi sistemlerini temsil eden mütehassisların bir araya getirilmesi de tavsiye olunduğu için, yeni bir "Teknisyenler komitesi» teşkil edildi. Bu ikinci Teknisyenler komitesi de 1926 ve 1927 de yaptığı toplantılarda dört anlaşma projesi hazırladı. Bunlardan ikisi vasıtasız (dolaysı) vergilerde ve veraset vergilerinde mükerrerliği önlemeğe matuftu; diğer ikisi vergi kaçakçılığının önüne geçmek veya tahsilâtı kolaylaştırmak için Devletlerin karşılıklı olarak birbirine idarî̀ yardımda bulunmasını derpis ediyordu.

Bu komitenin tavsiyesine uyularak, hükûmet mümessillerini ihtiva eden bir üçüncü Teknisyenler komitesi toplandı. (Daha önceki 
komitelere iştirak eden mütehassıslar resmen kendi devletlerini temsil etmiyorlardı). Hükûmet mümessilleri komitesi yukarda bahsettiğimiz iki tarafh anlaşma projelerini kabul (8) ve Milletler Cemiyetine bağı daimî bir maliye komitesinin teşkilini tavsiye ettí. $\mathrm{Bu}$ komitenin vazifesi aktedilen anlaşmaları yayınlamak, muktelif memleketlerin malî sistemlerini incelemek, önemli meseleler hakkında muhtıralar neşretmek olacaktı. Üẹ yılda bir seçilen 12 âzadan mürekkep Milletler Cemiyeti daimî malî komitesi çok esaslı faaliyette bulunarak bütün malî anlaşmaları neşretti; malî terminolojiyi birleștirmeğe, muhtelif memleketlerin mevzuatını incelemeğe çalıştı. Sayısız raporlar hazırladı. Vergi mükerrerliğini önlemek bahsinde en iyi yolun hangisi olduğunu araştırdı ve şu sonuca vardı ki, "en ziyade müsadeye mazhar millet» kaydını bu sahada müsbet netice vermesi şöyle dursun, işleri büsbütün karıştıracağı muhakkaktır. Bu sebeple anlaşmalara konan "en ziyade müsaadeye mazhar millet» kaydının malî meselelere şümulü olmadığı bilhassa tassih edilmeli ve iki veya çok taraflı anlaşmalarla mükerrer vergiyi ortadan kaldırmak yolu tutulmalıdır.

Yukarda bahsi geçen raporlar içinde en önemlileri iktisatçı mütehassısłar veya âlimler komitesinin hazırladığı rapor ile birinci mütehassıslar komitesinin raporudur. Bu raporiarda vergi mükerrerliği meselesi, sebepleri ,neticeleri ve hal çareleriyle birlikte mufassal olarak incelenmiştir.

İktisatçı mütehassısların raporu (9) vergi mükerrerliğinin iktisadî sonuçlarını tahlil etmekle başlar. (Mütehassısların bu husustaki fikirlerine daha önce temas etmiştik). Raporun ikinci kısmında vergi alma hakkını esası incelenmektedir. Devlete vergi almak yetkisini veren nedir? Eski bir nazariyeye göre vergi hakkı bir mübadeleye dayanır. Vergi, devlet tarafindan mükellefleri ve mallarımı korumak üzere girişilen masrafların ve mükelleflere yapılan diğer hizmetlerin bedelidir. $\mathrm{Bu}$ nazariye bugün umumiyetle terkedilmiştir ve mütehassısların belirttiği gibi, vergi mükerrerliği problemini halletmek bakımından da hiç bir imkân temin etmez.

Bugün revaçta olan nazariye ödeme kabiliyeti nazariyesidir. Va-

(8) Bu anlaşma projelerinin metni için, bk. Niboyet, s. g. makale, Recueil des Cours, 1930. t. 31, s. 30 - 33. - Projelerden birinin tercümesi yaz1nın sonuna eklenmiștir

(9) Bu raporun tam bir tahlili için, bk. Allix, Répétitions écrites, S. 30 ve müt; Sack, s. g. makale, Revue générale de droit international public, 1930, s. 132 ve müt. 
tandaşlar devlet hizmetlerinden az veya çok istifade etmelerine göre değil, kamu masraflarına ortak olmak hususundaki iktidarları nisbetinde vergi öderler. Fakat kamu masraflarına ortak olmak, maddî imkânlarından bir kısmını camia emrine vermek mecburiyeti nereden doğmaktadır? Son zamanlara kadar bu mecburiyete esas olarak kabul edilen prensip, siyasî̀ bağlılık (allégeance politique) prensibi idi. Tşbiiyet bağının Devlete karşı bazı haklar verdiği ve bir takım borçlar yüklediği muhakkak ise de, siyasî bağlılık prensibi meselâ ecnebilerin vergiye tâbi tutulması gibi bazı hâdiseleri izah edememektedir. Tâbiiyet esasının vergi alma hakkı için yeter bir temel teşkil etmediğini gören nazariyeciler muvakkat mesken, ikametgâh, servetin menşei veya bulunduğu yer (situs) gibi başka esaslar aramışlardır. Bu sonuncularda siyasî olmaktan çok iktisadî bir karakter göze çarpmaktadır. İşte servetin menşei, bulunduğu yer (situs), kullanıldığı memleket (ikametgâh) gibi unsurların bir nevi iktisadî bağlllık (allégeance économique) husule getirdiği, ve Devletin vergi alma hakkının siyasî bağlılığa değil, bu iktisadî bağhlığa müstenit olduğu ileri sürülmüștür.

Mütehassıslara göre, vergi, siyasî bağ göz önünde tutulmadan, mükellefin iktisaden bağlı bulunduğu devletler arasında taksim edilmelidir. Fakat iktisadî bağlllık unsurlarının ikisi veya üçü çatıştığı zaman hangisi ağır basacaktır? Gaye mükerrer vergiyi önlemek olduğuna göre, mükellefin ikamet ettiği memleketin hakkı mı, yoksa servetin elde edildiği veya halen bulunduğu memleketin hakkı mı tercih olunacaktır? Raporun son kısminda mütehassıslar işte bu ana - meseleyi halletmeğe çalışmaktadırlar.

Mütehassıslar mükerrer vergi meselesini halledebilecek dört usul tasavvur etmişlerdir:

a) Tenzil usulü: Yabanc1 memleketlerden gelen servet ve gelirlerden dolayı hariçte ödenmiş olan vergiler, memlekette ödenmesi icap eden vergiden indirilir. Bu usulde servet ve gelirin menşei esas ittihaz edilmiş bulunmaktadır.

Türkiyede oturan bir kimsenin Ynuanistandaki bir sınaî teşebbüsten temin ettiği veya Romanyada ölen bir kimseden miras olarak aldığı gelir ve servet evvelâ Yunanistan veya Romanyada vergiye tâbi tutulacak ve bu miktar, Türkiyede ödenmesi icap eden asıl vergi yekûnundan tenzil edilecektir. Bu usul alacaklı memleketlerin işine gelmez. Cü̈nkü mükerrerliğin önlenmesinden doğan bütün fedakârlık alacaklı memleketlerin sırtına yüklenmektedir. 
b) Muafiyet usulü: Birinci usulün tam aksidir. Bu usule göre, memleket dışında oturan kimselere giden servet ve gelir vergiye tâbi tutulmaz. Burada ikametgâh unsuru esas ittihaz edilmiştir. Meselâ Türkiyede bir smaî teşebbüs işleten bir Amerikalının bundan elde edeceği gelir Türkiyede vergiye tâbi olmiyacak, sadece gelir sahibinin ikametgâhında vergi ödeyecektir. Servet ve gelirin menşeinin bulunduğu memleket, ezcümle borçlu memleketler bakımından mahzurlu olan bu usul alacaklı memleketlerin menfaatlarina tamamiyle uygundur.

c) Paylaşma usulü: İki memleket vergiyi belli nisbetler dahilinde paylaşmak üzere aralarında anlaşacaklardır. Yukardaki misalde verginin bir kısmm gelirin elde edildiği memleket yani Türkiye, diğer kısmını gelir sahibinin mukim bulunduğu memleket, meselâ Amerika alacaktrr. Burada «iktisadî bağlllık (allégeance économique) derecesine göre paylaşma" prensibi tatbik edilmis bulunuyor.

d) Tasnif usulü: $\mathrm{Bu}$ usulde ise, vergi olarak tahsil edilecek meblâğlar değil de, vergi mevzuları paylaşııır. Bazı mevzulardan vergi almak hakkı bir devlete, diğerlerinden vergi almak hakkı ikinci devlete verilìr. Meselâ gayrimenkullerin "menşe» memleketinde, menkul servetlerin ise "ikametgâh" memleketinde vergiye tâbi tưtulması kararlaştırılabilir. Bu usul de iktisadî bağllık prensibine uygundur. Fakat, servet ve veraset vergilerinde kolay tatbik edilebilmesine karşıllık, umumî gelir vergilerinde büyük güçlükler arzeder. Meselâ Moranyada oturan bir kimse, İmeryadaki bir ziraî işletmeden gelir temin etmektedir. Bu gelir gayrimenkul geliri midir, işletme geliri midir? Buna benzer birçok hallerde menşe memleketinin hakları ile ikametgâh memleketinin haklarmı ayırmak zor olacaktır.

Bu dört usulü tesbit ettikten sonra, mütehassislar bunları muhtelif vergi nevilerine tatbike çalışmışlar ve veraset vergiferi ile gayrişahsî vergilerden işe başlamışlardır.

Birinci usul ikametgâh memleketine ağır fedakârıłlklar yüklemektedir. Üstelik bu fedakârlığın hudutları servet ve gelirin çıtı̆̆ı veya bulunduğu memleketin takdirine kalmıştır. Bu sebeple ancak Amerika Birleşik Devletleri gibi zengin ve vatandaş̧larının hariçte ticaret yapmaların teşvik eden memleketler bu usule katlanabilirler. İkinci usul de servet ve gelirin çlktı̆̆ı veya bulunduğu memlelekẹt bakımından fazla mahzurludur. Şu halde üçüncü veya dördün- 
cü usule başvurmak lâzımdır. Komite vergi mevzularının tasnifi usulünü (4 üncü usulü) tercih etmektedir: gayrimenkuller ve bunlara bağlı olan tesisat ve makinalar için menşe prensibi; esham ve tahvilât, menkul servetler için ikametgâh prensibi tatbik edilmelidir. Gemiler, kayıtlı bulundukları liman hangi menlekette ise orada vergi ödemelidir. Ticarî teşebbüsler için dördüncü usulün tatbiki kolay değildir: bunlar hakkında taksim usulü (üçüncü usul) tercihe şayandir. Şu halde ,veraset vergileri aynî vergilerde, bazan taksim usulü ile mezcedilmek şartıyla, tasnif usulü esas ittihaz edilmelidir.

Şahsî mahiyetteki geli rvergilerine gelince: burada komite bambaşka bir neticeye varmakta ve birinci, üçüncü, dördüncü usulleri elverişsiz, tatbiki imkşnsız diye bertaraf ettikten sonra, muafiyet usulünde karar kılmaktadır. Bu usulün ise, borçlu memleketlerin zararına olarak tamamiyle alacaklı memleketlerin menfaatlarinı sağlıyan bir usul olduğunu söylemiştik. Âlimler komitesinin bu tavsiyesi şiddetli tenkitlere yol açmış ve bu hükmün sebebini, komitenin münhasıran Holandalı ve Anglo-Sakson âlimlerden - yani münhasiran alacaklı milletler mümessillerinden - terekküp etmesinde arıyanlar olmuştur. (Gerçekten İtalyan profesörü çalışmalara iştirak edememiş ve hazırlanan raporu imzalamakla iktifa etmişti.) Âlimler komitesindeki dört üyeden biri olan Amerikalı profesör Seligman da, yapılan tenkitlere cevap verirken, raporun yalnız İngiliz, Holandalı ve AmerikaIr üç mütehassısın iștiraki ile hazırlanmış olmasının Lâtin memIeketlerinde ve diğer memleketlerde carî bulunan vergi sistemlerinin ihmaline yol açtığını itiraf etmiştir. Seligman'a göre, raporda bu memleketlerin vergi sistemlerine de temas edilmiș, fakat üzerinde fazla durulmamıştır (10).

Âlimler komitesinin aksine olarak, Teknisyenler komitesi daha ziyade borçlu memleketlerin mümessillerinden nürekkepti (11). Fakat teknisyenler komitesinin vardiğı neticeler de âlimler komitesinin başlıca tavsiyelerinden fazlaca uzaklaşmış değildir (12). O zamana kadar yapılmıs olan milletlerarası mukavelelerde bilhassa taksim usulüne başvurulduğunu müşahede eden teknisyenler, vergileri aynî ve şahsî olarak ayırmışlar; aynî vergilerin menşe mem-

(10) Seligman, s. \&. makale. Recueil des Cours, t. 20, s. 566 - 567.

(11) Belçika, Fransa, İngiltere, Holanda, İtalya, İsviçre, ve Çekoslovakya mümessilleri.

(12) Bilhassa bk., Seligman,s. \&. makale, Recueil des Cours, t. 20, s. 569 ve müt.; Allix, Répétitions écrites, s. 95 ve müt.; Sack, 5. g. makale, Revue générale de droit international public, 1930, s. 133 ve müt. 
leketine, şahsì vergilerin ise ikametgâh memleketine ait olması lâzım geldiği yolunda bir neticeye varmıslardır. Fakat muhtelif vergi mevzularını ve nevilerini birer birer ele alp incelerken, yer yer bu ana prensipten fedakârlıklar yapmışlardır: bir çok hallerde ikametgâh memleketi ile mal ve gelirin çlktığı veya bulunduğu memleketin - vergiyi aralarmda belli nisbetler içinde paylaşmak üzere anlaşmaları icap ettiğini belirtmişlerdir. Teknisyenler, sık sık bahsi geçen uikametgşh tabirinin vuzuhsuzluğuna da dikkati çekmişler ve bu mefhumu kesin olarak tarife çalışmışlardır. Fakat bütün vergi nevilerine şamil tek bir tarif yapmak kabil olmamıştir. Umumî gelir vergileri için, ikametgâh mükellefin daimî olarak oturduğu yerdir. Veraset vergilerinde ise, ikametgâh müteveffanın ölümü sırasmda daimî olarak yerleşmek niyetiyle oturduğu yerdir. Şirketler ve hükmî şahıslar için, kanunî merkez veya teşebbüsün fỉilî merkezi ikametgâh sayılabilir.

Daha sonra toplanan ikinci teknisyenler komitesinin ve hükûmet mümessilleri komitesinin de ayni esaslara sadik kalarak bazı anlaşma projeleri hazırladıklarını yukarda söylemıștik.

Devletler hukuku Enstitüsünün, Milletler arası Tisaret odasınun ve bilhassa Milletler Cemiyetinin bu çalışmaları, mîkerrer vergiyi önlemek üzere milletler arası anlaşmalar yapılmasım kolaylaştırmış ve teşvik etmiştir. Gerçi daha geçen asrm ortalarından itibaren komşu ve bilhassa ahalisi birbirine akraba olan memleketler arasinda - daha çok veraset vergilerine taallak eden - bir takm: anlaşmalar yapılmıştı. Fakat 1921 den sonra bu anIaşmaların sayısı hızla kabarmış ve ikinei dünya harbinin başına kadar 140 a baliğ olmuştur. Milletler Cemiyeti mali komitesi bunları bir "recueil" halinde neşretmiştir (13). Fakat anlaşmaların mühim bir kısmı bütün vergilere şamil olmayıp, pek mahdut bir sahaya taallitk etmektedir. Muhtelif memleketlerin vergi sistemleri arasindaki derin farklar göz önünre tutulunca, daha geniş anlaşmalar yapmaktaki güçlükler kendilì̆ginden anlaşlır (14).

$\mathrm{Bu}$ güçlüğü gören bazı müellifler, ezcümle Griziotti, Milletler Cemiyetinin vergi mükerrerliği meselesini kökünden halletmek için, dünya ölçüsünde bir malî islahat yapmasını ve malî sistemleri birleştirmeğe çalıșmasını istemişlerdir. Griziotti'ye göre, Milletler Ce-

(13) 1928 e kadar yapılan anlaşmaların tam bir listesini bulmak için, bk. Seligman, s. g. makale, Recueil des Cours, t. 20, s. 503 - 504.

(14) Niboyet, s. g. makale, Recueil des Cours, t. 31, s 63 - 65 ve 67. 
miyeti, dünyanın en yetkili maliyecilerinin yardımı ile ,muhtelif memleketlerde yürürlülkte olan malî sistemlerin tenkidî bir etüdünü yaptırmalı ve muhtelif memleketlerin ihtiyaçlarma uygun rasyonel vergi nizamları bulmalıdır. Böylece malî sistemler ana tiplere irca edilecek ve bugün Devletlerin malî sahada anlaşmalarını imkânsız kılan 'birçok prensip ve menfaat zıddiyetleri ortadan kalkmış olacaktır. Bu da yalnız vergi mükerrerliğini önlemekle kalmayıp, milletler arası mübadeleyi kolaylaştıracak, milletler arası vergi kaçakçıllı̆ını yokedecektir (15).

Einaudi de, vergi mükerrerliğini önlemek için, malî sistemlerin ıslahını ve birbirine yaklaşmasını lüzumlu görmektedir: Muhtelif milletlerin kanun yapıcılarmm zihniyetlerinde bir yakmlık husule geImedikçe, kanun yapıcıların hareket noktaları ve ana fikirlerinde iştirak olmadıkça, yazılı mukavelelerden doğacak mahdut işbirliği büyük faydalar sağlıyamaz (16).

Fakat Allix'in belirttiği gibi (17), tarihten, geleneklerden, fark$l_{1}$ adalet telâkkilerinden ve iktisadî, içtimaî zaruretlerden doğan mukavemetleri hesaba katmaksızın malî sistemlerin birleștirilmesinden bahsetmek, bugün için, hayale kaprlmak demektir. Hattâ sadece vergi mükerrerliklerini önlemek gibi mütevazi bir gaye güden anlaşmaların bile cihanşümul bir mahiyet almasına şimdilik ihtimal yoktur. Çok taraflı anlaşma teşebbüsleri her defassında akamete uğramıştır. 1922 de Romada, Avusturya - Macaristan imparatorluğunun vârisi olan Devletler arasında yapılan çok taraflı malî anlaşma, neticede yalnız İtalya ve Avusturya tarafından tasdik edilmiştir. 10 kadar devleti bir araya toplamağa muvaffak olan biricik anlaşma, yabancilara ait otomobillerin malî durumunu tesbit eden Cenevre protokoludur.

Niboyet'nin bilhassa işaret ettiği gibi (18), vergi mükerrerliği meselesinin nazarî olarak halledilebilmesi bile büyük güçlükler arzeđer. Sadece nazarî bakımdan "vergi koymağa yetkili" olan memleketin tesbiti kâfi değildir. Birçok tâli noktalar üzerinde de karara varılması Iâzımdır: Ezcümle ikametgâhm tarifi; malların tasnifi (hangi malların menkul, hangilerinin gayri menkul sayılacağı); malların bulunduğu yerin tesbiti (gayri maddî mallarm, meselâ alacakIarm yeri neresidir); vergilerin tavsifi (hangi vergiler vasitalı,

(15) B. Griziotti, s. g. makale, Recueil des Cours, t. 13, netice.

(16) I. Einaudi, s. g. makale, Recteil des Cours, t. 25, s. 113 - 114.

(17) Allix, Répétition écrites, (doktora kuru, 1937 - 38), s. 296 - 300.

(18) Niboyet, s. g. makale, Recueil des Cours, t. 31, s. $70-80$. 
hangileri vasıtasız, hangi vergiler aynî, hangileri şahsîdir); cemiyetlerin ve diğer hükmî şahısların statüsünü tâyinde hangi memleket hukukunun esas tutulacağı; zaman içindeki birçok ihtilâfların nasıl halledileceği (meselâ malî yıl zarfmda yer değiştiren mükellefin vergi durumunun ne olacağı) gibi bir çok meseleler üzerinde anlaşmak gerektir.

Görüldüğü gibi, milletler arası vergi mükerrerliği sahasında, büyük hamleler yaparak birdenbire geniş anlaşmalara varmak kolay değildir. Bu sebeple Milletler Cemiyeti mütehassıslar komitesi de (1927) raporunda iki taraflı anlaşmalar yolunu tavsiye etmektedir (19). İktisatçı mütehassıslar komitesinde çalışmış olan profesör Seligman ise, daha nikbindir: cihanşümul anlaşmalar yapılabilmesi şimdilik imkânsız da olsa, vergi sistemleri az çok birbirini andıran milletler (meselâ Amerika, Ingiltere, Almanya, Holanda; -- veya Lâtin memleketleri) arasında pekâlâ çok taraflı anlaşmalar yapılabilir. Diğer taraftan veraset vergileri gibi bazı sahalarda, cihanșümul anlaşmalara varabilmek nisbeten kolaydır. Sinaî inkilâp ve bunun doğurduğu iktisadî hayat, millî camiaların yanıbașinda bir "dünya camiası" nın mevcudiyetini insanlara kabuỉ ettirmiştir. Nasll ki ayni devlete tâbi olan fertlerin işbirliği, her birinin bazı fedakârlıklarda bulunmasını ve müşterek bir gaye için gayret sarfetmesini gerektiriyorsa; Devletler arası münasebetlerin de karşllıklı fedakârlık ve müşterek bir gayeye bağlllık temeline dayanması lâzım - geldiği ergeç anlaşlacaktur. Vergi sahasmdaki işbirliği siyasî hayatın her sahasında doğacak olan işbirliğinin bir cephesinden ibarettir (20).

Seligman bu ümit dolu satırları yazdıktan sonra dünya pek karanlık ylllar geçirdi. Fakat şuna inanryoruz ki, bu feci ve amansız harp yılları bütün milletlerin "tek bir dünya» da yaşadığını ve milletler arası işbirliğinin lüzumunu eskisinden daha kuvvetle açığa koymustur. Bu derslerin tamamiyle faydasız olduğuna kani değiliz. Eski Milletler Cemiyetinin çalışmalarmı devralan Birleşmiş Milletler teşkilâtının, milletler arası vergi hukuku sahastnda yeni ilerlemeler temin edeceğinden eminiz (21).

(19) İdem, s. 58 - 59; Henri Bloch, Malî işlerde karşılıkît yardtm, Maliye mecmuasi, sayı 5, s. 57 (Revue de science et de législation financières'den).

(20) Seligman, s. g. makale, Rectueil des Cours, t. 20, s. 589 - 595.

(21) Bu sahadaki çalışmalar harp içinde de devam etmiş, yeni anlaşmalar imzalanmıștır. Bunlarun en yenisi, bildił̆imize göre, Ingiltere ile Amerika arasında 1945 de yapılan «veraset vergilerinde mükerrerliği önlemeǧe matuf anlaşma» drr. 
Yazımıza son vermeden önce, biraz da milletlerarası vergi mükerrerliği bakımından memleketimizin durumuna temas etmek yerinde olacaktrr.

Memleketimizin durumu: Bizde, uzun zaman, vergi mükerrerliği meselesiyle değil, tersine olarak yabancıların başlıca vergi ve resimlerden muafiyeti meselesi ile uğraşmak icap etmiştir. Bunun da sebebi kapitülâsyonlardır.

Yukarda gördük ki, verginin iktisadî bağlılık (allégeance économique) temeline dayanması, yabancıların vergiden muafiyeti için hiç bir sebep bırakmamıstır. Yabancı, ikamet itibarile veya servet ve geliri itibarile ilgili olduğu siyasî camianm vergilerine iştirak etmek zorundadır. Kaldı ki, yabancıların vergiye iştiraki, yalnız adalet bakımından değil, iktisadî rekabet bakımından da elzemđir. Aksi halde ,iktisadî mücadele sahasında yabanct yerliden daha üstün bir duruma geçer ve memleketteki teşebbüs kuvveti zayuflar (22).

Nitekim bizde, Birinci Cihan Harbine gelinceye kadar yabancıIarm ne temettü vergisi ne de esnaf tezkeresi resmi ödememeleri yüzünden, yerli unsur daima iktisaden daha zayıf durumda kalmıştır. (Birçok yerli gayrimüslimler de yabancı tâbiiyetine geçmek veya ecnebi himayesine sığınmak suretile vergiden kurtulmağa muvaffak olmuşlardır).

Ecnebiler bu muafiyetlerini kapitülâsyonlara istinat ettirmişlerdir (23). Fakat muhterem hocam Ibrahim Fazıl Pelin'in de belirttiği gibi, ecnebilerin ancak geçici olarak ticaret yaptıkları bir devirde kabul edilen ve memlekete daimî surette yerleşenlere şamil olduğu pek şüpheli bulunan bu muafiyetlerin ithalât, ihracat, banka işleri gibi en mühim ticaret şubelerini ellerinde tutan ecnebilere de tatbik. edilmesi adalete ve millî egemenliğe her bakımdan aykırı idi. Buna rağmen, yapılan müzakereler Avrupa Devletlerinin emperyalist emelleri karşısında hiç bìr netice vermedi, sürüncemede kaldı. Vergi kanunlarımızın fenalığından, tazyiklerin fazlalığından dem vuruluyordu. Avrupa devletlerine hoş görünecek bir vergi sistemine kavuşmak için kararnameler, projeler hazırland. Fakat bunların hepsi

(22) İ. Fazıl Pelin, s. \&. e., Vergide umumiyet bahsi, bithassa s. 152.; P. Fauchille Traité de droit international public, t. I. Première partie, Paris, 1922, s. 933.

(23) Bu hususta ve yabanc1larin vergì mükellefiyetinin Lozana kadar geçirdiği safhalar hakkında, bk. I. Fazıl Pelin, s. g. e., s. $348-350$ ve \&Beynelmilet Ticaret ve finans münasebetleri bakrmmdan Türkiye», Üniversite Konferanstart, 1935 - 1936, s. 336, bilhassa s. 345 ve müt.

Hukuk Fakültesi Mecmuası 
itiraza uğruyor, karşı tarafın kötü niyeti yüzünden müzakereler bir türlü sona ermiyordu. Bu arada, muahedelerine eklenen bazı maddelerle, Bosna - Herseğin kaybı sırasında Avusturyanın, Trablusgarbin kaybı strasinda İtalyanin muvafakati alınabildi.

Umumî Harp başladıktan sonradır ki, 1 mart 1915 tarihli kanunla, yabanclar Osmanlı tebaaları ile ayni şekilde ve ayni sıfatla her türlü vergi ve mükellefiyetlere tâbi tutuldular (24). Mütarekede iade edilen kapitülâsyonlar Lozan muahedesinin 28 inci maddesi ile kökünden kaIdırıldı. Bu muahedeye eklenen «tkamet ve selâhiyeti adliye hakkındaki mukavelename" ye de âkit devletler tebaalarmn Türk tebaasını̣ tâbi olduğu vergi, rüsum ve tekâliften başka veya daha ağır bir gûna vergi, rüsum ve tekâlife tâbi tutulmıyacağı yolunda bir hüküm kondu. Bu suretle Türk vatandașı ile yabancı arasinda vergi müsaviliği teessüs etmiş oldu.

$\mathrm{Bu}$ mexhale böylece aşıldıktan sonradır ki, vergi mükerrerliğini önleyecek bazı hükümler de kanunlarımızda yer aldı. Bunlar milletler arası anlaşmalara dayanmayıp, tek taraflı olarak Türk kanın vazı tarafmdan kabul edilen hükümlerdir. 1931 de geniş ölçüde tâdil edilen 1926 tarihli "Veraset ve intikal vergisi" kanunumuz, mükellefi, hem ikametgâh esasına, hem de menșe esasma göre vergiye tâbi tutmaktadır: Bir kere, Türkiyede oturan bir kimseden, kendisine haricten intikal eden mallar için dahi vergi alınır (ikametgâh esası); diğer taraftan intikalin mevzuu olan amal, hukuk ve menafi" Türkiyeden çktığı takdirde, bunların intikal ettiği kimse hariçte de otursa, yine vergi alınır (menşe esası). Fakat, bu halin vergi mükerrerliklerine yol açabileceği düşünülerek, bazi tedbirler alınmıștır. 1931 tarih ve 1836 sayılı kanunla değiştirilen 20 nci madde mucibince: "ikametgâhı Türkiyede bulunan müteveffa veya tasarrufu yapan şahıstan intikal edip de yabanc memleketlerde bulunan menkul ve gayri menkuI malların vergilerinden, bu memleketlerde alındığ sabit olan veraset ve intikal vergisì tenzil olunur." Görüldüğü gibi, burada, Milletler Cemiyeti âlimler komitesinin tavsiye ettiği dört usuldẹ birincisi olan tenzill, usulü kabul edilmiştir.

Diğer taraftan, 1934 tarihinde Büyük Millet Meclisinden geçen 210 sayll bir tefsir kararma göre, Türkiyede mukim bir yabancıya intikal edip yurt dışında buIunan mallardan vergi alınmaz. Kanaatımızca bu sonuncu muafiyet pek lüzumlu değildi. Cünkü malların bulunduğu memleket hiç vergi almadığı takdirde bizim de veraset

(24) P. Fauchille, s. g. e., s. 959. 
ve intikal vergisi almamamı için makul bir sebep yoktur. Diğer taraftan, bu tefsir kararı yabancıları, Türkiye Cümhuriyeti tebaalarmdan daha iyi duruma sokmak suretile vergi eşitliğini lüzumsuz yere ihlâl etmektedir. Yirminci maddede olduğu gibi, hariçte ödenmiş olan verginin tenzili ile iktifa edilebilirdi.

"Kazanç vergisi” kanunumuz bazı vergi mükerrerliklerine yol açmaktadır (25). Kanun, mükellef olarak sıraladığı gerçek ve tüzel kişilerin bütün kazançlarını vergiye tâbi tutar. Tasarıdaki "Türkiye Cümhuriyeti dahilinde... temin ettikleri» kaydı sonradan kaldırılarak, menşei hariçte olan kazançlar da vergi mevzuuna ithal edilmiştir. Bununla beraber, hizmet erbabı için, kanunda vergi mükerrerliğini önIemeğe matuf bazı hükümler vardır. Kanunumuz hizmet erbabinın teklifi bahsinde ikametgâh esasını kabul etmiştir. Bu, yukarda bahsettiğimiz dört usulden ikincisine (muafiyet usulüne) tekabül etmektedir. 29 uncu maddeye göre, hariçteki bir ecnebi müesseseye bağlı olup da Türkiyede oturan memur ve komisyoncu kabilinden hizmet erbabı kazanç vergisine tâbidir. Buna karşllık, Türkiyedeki müesseselere bağlı olup da devamlı surette hariçte oturan hizmet erbabi - o memlekette vergi ödediklerini isbat etmek şartiyle - vergiden muaftır. Şu noktayı belirtelim ki, bu madde, memleket müesseselerine mensup olup da hariçte ikamet edenleri vergi mükerrerliğinden korumağa muktedir olmakla beraber, yabancı memleketlerdeki müesseselerin Türkiyedeki mensuplarmı korumağa kâfi değildir. Çünkü bu sonuncular ikametgâh esasına göre Türkiyede vergi ödedikleri gibi, menşe esasma göre de müessesenin bulunduğu memlekette vergi ödeyebilirler. Hazineden daha fazla fedakârlık yapmaksızın bu gibi mükerrerlikleri önliyebilmek için, devletler arası anlaşmalar akdetmek lâzım geldiği âşikârdır.

Diğer taraftan, kazanç vergisi kanunumuz hariçte şubesi olan müesseseler hakkinda sarih bir hüküm ihtiva etmemektedir. Türkiyede yerleşmis olan veya yerleşmiş sayılan (yani şube açan, sabit tesisat vücuda getiren ve alım - satım yahut satım işiyle iştigal eden) ecnebi müesseseler - rekabet ve vergi eşitliğini korumak için - vergiye tâbi tutulmuștur. Buna mukabil, yerli müesseselerin yabancı memleketlerdeki șubelerinin kazancm vergiden muaf tutan sarih bir hüküm mevcut değildir. Bu hal şüphesiz vergi miükerrerliklerine yol açmaktadır. Bu mükerrerliklerin de fazla fedakârlık yapmaksızın önlenebilmesi milletler arası anlaşmalar aktedilmesine bağlıdır.

(25) Bu hususta bk., İbrahim Faztl Pelin, s. s. e., s. $356-357$ ve s. 234. not2. 
Halbuki, bildiğimize göre, $3 / 5 / 1934$ tarih ve 2424 sayll kanunla tasdik edilen Cenevre protokolü hariç, memleketimiz vergi mükerrerliğine müteallik hiç bir milletler arası anlaşma yapmış değildir. Bunun bir sebebini vergi sistemimizin başlıca milletlerarası anlaşma sisteminden fazlaca farklı oluşunda arayabiliriz. Gerçekten, vergi sistemleri arasmdaki farkların genişliği nisbetinde mükerrerliği önlemek için anlaşmalar yapilabilmesi güçleșir (26).

Bundan daha mühim bir sebep de, vergilerimizin umumiyetke aynî (gayri şahsî) oluşudur. Yukarda da işaret etmiştik ki,(27) arazi vergisi, bina vergisi gibi mülkî ve aynî mahiyetteki vergiler mükerrerlik hallerinin husule gelmesine pek elverişli değildir. Halbuki mükellefin servet ve gelirini kül halinde ele alan ve zilevî, şahsî durumunu göz önünde tutan vergiler mükerrerliğe daha çok yol açar.

Şu halde bizim vergilerimiz içinde mükerrerliğe sebebiyet verebilecek olanlar bilhassa veraset vergimizle, yarı — şahsî kazanç vergimizdir.

Projesi hazurlanmakta bulunan Umumî Gelir vergisinin tatbikine geçildikten sonra, hem mükerrerlik ihtimalierinin artması, hem de vergi rejimimizin ileri memleketlerin sistemine yaklaşması dolayısıyla bizim de mükerrerliği önlemeğe matuf bazı anlaşmalar yapmamız beklenebilir. Bu gibi anlaşmalar yalnız vergi rejimimizin daha âdil olması bakımından değil, vergilerimizin verimliliği ve milIetler arası iktisadî münasebetlerimizin gelişmesi yönünden de faydalı olacaktır.

\section{E K}

Milletler Cemiyetinin topladığı üçüncü teknisyenler komitesi tarafından kabul edilen "veraset vergilerinde mükerrerliği önlemeğe matuf anlaşma tasarısı" nin tercümesi: (Niboyet'nin makalesinden naklen, Recueil des Cours, t. 31, S. 32).

\section{Madde 1}

$\mathrm{Bu}$ anlaşma âkit devletlerin mükelleflerini veraset vergileri sahasınđaki vergi mükerrerliklerinden korumağa matuftur.

(26) Niboyet, s. \&. makale, Recueil des Cours, t. 31, s. 67.

(27) Bk. s. 4. 
Bu anlaşma mucibince "veraset vergisi» telâkki edilen mükellefiyetler aşağıda gösterilmiştir:

a)

b)

c)

\section{Madde 2}

Veraset vergileri müteveffanın ikametgâhının bulunduğu memleket, yani ölümü sırasinda devamlı surette kalmak niyetiyle mesken ittihaz ettiği memleket tarafından alınır. Memleket dişında bulunanlar da dahil olmak üzere, müteveffanın braktığı bilcümle mallar hesaba ithal edilebilir; fakat, lüzumu halinde, 4 üncü maddede gösterilen tenzilât icra olunarak, geriye kalan kısım tahsil edilecektir.

\section{Madde 3}

Akit memleketlerin birinde mukim bulunan müteveffa diğer leket dahilinde 4 üncü maddede gösterilen nevilere girebilecek mallar birakmis ise, sonuncu memleket mezkûr mallardan veraset vergisi alabilir; fakat bu vergi başka herhangi bir memlekette bulunan meveudat ve matlubat (aktif) hesaba katılmaksızın, sadece mezkûr malların kıymetleri üzerinden hesaplanmak iktiza eder.

\section{Madde 4}

Yukardaki maddelerin ayni zamanda tatbikinden doğabilecek vergi mükerrerliğini önlemek gayesiyle, müteveffanın ikametgâhlnın bulunduğu memleket, aşağıda tasrih edilen mal nevileri için, şu iki miktardan en küçüğünü vergiden tenzil etmeğe rıza gösterecektir:

a) Memleket dışında bulunan mevcudat ve matlubat üzerinden, ikametgâh Devletinin bilfiil tahakkuk ettirdiği vergi.

b) $\mathrm{Bu}$ mevcudat ve matlubat üzerinden, bulunduklarn memlekette bilfiil ödenecek olan miktar.

Yukarda adı geçen mal nevileri şunlardır:

a) Gayri menkuller ve onları teçhize yarayan menkuller.

b) Âkit devletler arasında bilmukavele tesbit edilebilecek olan bütün diğer mal nevileri.

\section{Madde 5}

Muayyen mallara terettüp eden veya muayyen mallar ile teminat altına alınmış bulunan borçlar, bu mallara mahsub edilir. 
Diğer borçlar, âkit taraflar arasında yapılacak hususî anlaşmalara tevfikan tesbi tedilecek olan muhtelif mal nevileri arasinda paylaştırilır.

\section{Madde 6}

$\mathrm{Bu}$ anlaşmanın hükümlerinin tefsiri veya tatbiki hususunda âkit devletler arasında bir ihtilâf zuhûr ettiği ve bu ihtilâf gerek doğrudan doğruya iki devlet arasında, gerek başka herhangi bir dostane tesviye usuliyle halledilemediği takdirde, Milletler Cemiveti Konseyinin tâyin edeceği bir teknik teşekküle tevdi edilebilir. Bu teşekki" iki tarafı dinledikten ve icabında bir araya getirdikten sonra, istişarî mahiyette olmak üzere, mütalâasmı bildirir.

Âkit devletler, bu müracaattan önce, mezkûr teşekkülün serdedeceği mütalâanın kat'î mahiyette olmasını kararıaştırabilirler. Aksi takdirde bu mütalâa âkit devletleri bağlamaz, meğer ki her iki devlet tarafindan kabul edile. Taraflar, gerek yukarda zikredilen usule başvurduktan sonra, gerekse bu usulün yerine kaim olmak üzere hakeme veya kazaî bir mercie müracaatta serbesttirler; Státüsü mucibince yetkili olduğu bütün mevzularda, Milletlerarası Daimî Adalet Divanına da başvurabilirler.

Yukarda bahsi geçen teşekkülün işe el koyması veya bu teşekkülün serdedeceği mütalâa, ihtilâf mevzuu olan tedbirin kaldrrrlmasını icap ettirmez; Milletlerarası Daimî Adalet Divanına müracaa ${ }^{+}$ edilmesi halinde de vaziyet böyledir; fakat Divan, Statüsünün 41 inci maddesi gereğince başka şekilde karar. verebilir. 